\title{
今井照
}

\section{1 「移動する村」}

近世の村は土地の区画ではなくて、人の集 合体を意味していた。したがって、干ばつや水 害等の自然災害が起きて、その地が耕作困難に 陥るなどの事情を生じると、村ごと場所を移動 することがあった（「移動する村」）。その場合、 土地が変わっても村の名前は変わらない。なぜ なら、村の名前は固有の土地を指すのではなく、 村という人の集合体を指すからである。

こうして幕末には藩の飛び地が一般的になっ ていく。したがって、藩もまた土地の区画では なくて、領主が住む町を中心とした複数の村か ら成る関係の概念である。土地の区画のほうは、 陸奥国といったように「国」や「郡」で示され る。廃藩置県というのは、単に藩を廃して県を 置いたというのではなく、統治の構造を人の集 合体である藩－村という関係から県一郡という 土地の区画に再編したということがいえる。

藩－村という関倸の概念で統治が成立してい たのは、年貢の単位が村だったからである。藩 は村に対して年貢を割り当てる（村請制）。村 は割り当てられた年貢を村民で分担する。何ら かのアクシデントがあって年貢を納められない 村民がいたとすると、村は他の村民から融通す るか融資をするなどして村全体の年貢を確保す る（松沢裕作『町村合併から生まれた日本近代』 講談社、2013年)。藩にとっても徵税の手間が 省けるので便利がよかった。したがって、村民
にとって村とは、生活を守るための保護の単位 であるとともに、年貢を課せられる規制の単位 でもあった。村という政治的共同体は統治の単 位であり、したがって、村の内部には相互の縛 り（「絆」）が存在する一方で、村としての自治 も発生した。

明治維新政府は近代化と集権化を志向する。 藩や村という中間団体の存在は望ましくない。 そこで藩を解体し、さらに村を換骨奪胎しょう とする。国家統治に都合のよいところは村の自 治を尊重しつつ、包括的に村を国家行政機構の 一端に繰り込んでいった。租税は村ではなくて 個人に対して課すようにする。そこで課税対象 としての個人を特定するために、戸籍法の制定 等を通じて、個々人をそれぞれの土地とリンク させて管理しようとした。

こうした試みはさまざまな抵抗を生み出しな がら紆余曲折を経て成立した。土地とリンクし て人を管理しようとする試みも人が流動性を高 めれば高めるほど複雑化していった。身分認証 や出身地管理としての戸籍だけでは「国民」を 管理できず、ただちに寄留制度が生まれ、後に 寄留法の制定から、戦後の住民登録法、現在の 住民基本台帳法を生み出していく。その一方、 戸籍制度は形がい化しつつ残存しているので、 いまや世界的にもまれな戸籍と住所の二重管理 体制が構築されるに至った。

この過程は、しばしば自然村から行政村へと いう文脈で説明されることがある。しかし、近 
世においてすら自然村ということばがイメージ させるような牧歌的、自己完結的な農村共同体 が存在していたわけではない。既に村は統治の 一翼を担っていたので、後に行政村と呼ばれる ことばが意味するような「行政の下請け」機能 を十分に果たしていた。したがって、自然村か ら行政村へという説明はミスリードを起こしや すい。

\section{2 原発災害避難自治体の 出現から学ぶもの}

2011 年 3 月 11 日の東京電力福島第一原子力 発電所による災害は現代に「移動する村」を出 現させた。原発災害直後、双葉郡の 8 町村が自 治体丸ごと避難を決断した。その後、飯舘村が 加わり、広野町と川内村が帰還したが、現在で も7町村が役場を含めて全域避難を続けている （この他に、南相馬市、田村市、川俣町の一部 地域が避難を続けている)。

もちろん、ここで近代的な統治構造に組み込 まれた現在の市町村と近世の村とを混同させる わけにはいかない。しかし、これらの町村の推 移と現在を見る限り、近世の「移動する村」が 現代に出現したと感じることが多々ある。現に、 広野町、川内村、暮尾村は明治以降合併を経験 していない町村であり、その他の町村も平成の 大合併を経験していない。

むしろこれからの自治体再建にとっては、こ

\section{PROFILE}

今井照

(いまい あきら)

福島大学行政政策学類教授

専門: 自治体政策
こで垣間見られる自治体の原像を積極的に評価 し、そこに根拠を求めるべきではないかと考え ている。それは7町村のみならず、国の統治構 造の末端に組み込まれてしまった全国の自治体 を市民生活や地域社会から再構築させるヒント になるのではないか。国家という統治機能を一 般的に否定するわけではないが、市民の生命と 生活を最後に守るのは自治体のミッションであ り、このことが市民全体の豊かな暮らしを導く と思われるからである。

こういう観点から『自治体再建 - 原発避難 と「移動する村」』（ちくま新書、2014年）を公 刊した。ここでは原発災害直後の市町村の動き を整理しながら、今後の自治体再建と避難者の 生活再建、特に「住まいの再建」について論述 した。しかし、新書という性格上、割愛しなけ ればならなかったことや舌足らずに終わってし まった部分もあるので、本稿ではここに盛り込 めなかった論点を含め、避難者の「住まいの再 建」とそれを通じた自治体の再建について考え てみたい。 


\section{3 「帰還」移住」に次ぐ第三の道}

2014年4月 1 日に予定されている田村市の旧 都路地域に対する避難指示の解除は、避難者 の生活再建にとって重大な意味を持つことにな る。現在、原発災害避難者の意向は大きく三つ に分かれる。ひとつは、元の地域に戻って生活 をしたいというものであり、その前提として元 の地域環境に近づけるための除染が条件となっ ている。完全な除染というのは想定できないの で、一定程度の除染が完了して元の地域環境に 戻ったと判断できる人たちが帰還することにな る。田村市の旧都路村地域における避難指示解 除と帰還はこうした観点からの方策であり、国 が一貫して追求してきた原発災害対策でもあ る。このことを待ちわびていた人たちに対して は「朗報」であろう。

しかし、このことは他の二つの意向を持つ 避難者にとっては切り捨てでもある。避難者の 第二のグループは、移住を選択する人たちとな る。避難先や新しい地域での再出発を期す人た ちである。もちろん、元の生活がそのまま維持 できていればこのようなことを考える必要がな かったが、事故が起きてしまった以上、現実と のすり合わせを迫られる。子どもの健康のこと、 仕事のこと、親のこと、生活環境のことなど、 さまざまな要素を考えて新しい土地での新しい 生活を目指す。事故によって強制的に迫られた 選択ではあるが、こういう生き方も否定するこ とはできない。
ところが、避難指示の解除によって、これ らの人たちの選択は自分たちが「勝手」に決め た生き方になってしまう。なぜなら「元の地域 に戻ろうと思えば戻れる」ことにさせられてし まうからである。この結果、本来は元の地域と 同等のレベルでの移住が賠償によって保障され なければならないはずなのに、逆に、一定期間 で賠償が打ち切られるということになってしま うのである。2013年 12 月 20 日に閣議決定され た「原子力災害からの福島復興の加速に向けて」 では、移住への支援が盛り込まれたものの、そ の対象は「帰還困難区域」の住民に限られてお り、大部分の避難者にはあてはまらない。しか も「支援」に過ぎず、元の住まいを再建できる 再調達価格による賠償ではない。

この「帰還」と「移住」以外に、避難者に は第三のグループがある。「中央」目線では理 解不能と思われるような「もう少し避難を続け ていたい」と考えている人たちである。避難生 活環境はますます劣悪になっている。仮設住宅 も3年目を迎えるとあちらこちらでトラブルが 起きている。もともとしっかりした基礎の上に 建っているわけではないので、建物が傾き始め ているところもある。床が抜けたり、壁が結露 でかびてくるといったことは日常茶飯事のこと である。にもかかわらず、もう少し避難生活を 続けたいという人たちがいるのはどうしてか。

ひとつは、「帰還」や「移住」という判断が つかないということである。なぜ判断がつかな いのかについても合理的な理由がある。まず、 
そもそも帰還できる環境にはない。除染しても なお存在する放射能污染はもちろんのこと、商 店やインフラなどの生活環境が整っていない、 長年の避難生活で自宅が劣化し補修や建て直し が必要になっている、農業や酪農を再開するこ とができないなど、個々の事情が山積してい る。また、災害公営住宅などへの一時的待避も 考えていない。なぜなら、災害公営住宅もほと んどは地域外にあり、再度の「避難」に過ぎな いからである。そこでもう一度最初から始める よりは、今のまま、もう少し避難生活を続けて いたいというのも無理はない。

この場合「もう少し」という期間が問題にな る。 2 年や 3 年かもしれないし、 20 年や 30 年か もしれない。あるいは子どもの世代、孫の世代 までも考えているかもしれない。いずれにして も、今すぐ行動するのではなくて「もう少し」 の間、避難を続けていたいのである。

しかし、この第三の選択については一切手立 てが講じられていない。避難指示の解除が始ま れば、第二の「移住」グループが「勝手」に地 域を出ていった人たちになってしまうのに対し て、この人たちは「勝手」に避難している人た ちになってしまう。もし従前の制度のままでい けば、仮設住宅は取り壊され、支援や賠償も打 ち切られる。住まいや生活の再建どころではな い。むしろ切り捨てられていくのである。

\section{4 喫緊の課題と中長期的課題}

この第三のグループのことを、「帰還」「移住」 に対して「超長期避難」と名づけておくことに する。現時点では、この「超長期避難者」に 対する政策的制度的な対応が全く行われていな い。なぜなら、これまでの災害救助法制は自然 災害を対象にしたものであり、今回の原発災害 についても既存の災害救助法制を援用している にすぎないからである。

自然災害の場合は、たとえば川の水があふれ そうになったので近所の学校体育館に避難する といったことが基本で、地震や津波による大災 害においても、これまでは一定の期間で元の地 域に戻るということが前提となった支援制度に なっていた。だから、仮設住宅の入居期限は 2 年間で、事情によっては 1 年ずつ延長し、災害 公営住宅が一定程度整備されればそこで「避難」 は打ち切られ、支援は終了した。

しかし、今回の原発災害は広域・超長期避難 であり、自然災害対応の救助法制では支援が行 き届かない。たとえば仮設住宅が劣化してきて も、それを建て直すという発想には至らない。 また、「みなし仮設」と呼ばれるアパートや貸 家居住についても、家族の成長や変化によって 住み替えることが認められていない。住み替え たらそこで支援が打ち切られる。避難が終了し たとみなされるのである。

このような環境の中で、しだいに避難して いることが何か悪いことをしているかのように 
なってくる。事故の被害者であるにもかかわら ず、息をひそめて暮らさざるを得なくなってし まうのである。住民税を支払っていないのに生 活ごみを出すことについて、周囲の人から何を 言われているかわからないとか、外食や買い物 すら周囲の目を気にしなくてはならなくなる。 一方、避難元の人たちに対しても、どこかに申 し訳なさが生じて、復興計画について言いたい ことも言いづらくなるといったこともありう る。

以上のことを考えると、原発災害避難者に対 しては喫緊の課題としての「住まいの再建」と、 中長期的課題である「市民権の保障」という二 つの対応が必要になってくることがわかる。日 本学術会議社会学委員会東日本大震棪の被害構 造と日本社会の再建の道を探る分科会は 2013 年6月27日に提言を出している（「原発災害か らの回復と復興のために必要な課題と取り組み 態勢についての提言」）が、2013年度末に向け ては、同じ組織が最終提言を予定しており、さ らに、日本学術会議の東日本大震災復興支援委 員会福島復興支援分科会も同じ時期に提言を予 定している。

改めて、現時点での緊急的な避難者対応を私 なりに整理すると次のようになる。

（1）住まいの再建

(1)「帰還」希望者に対して

・震災前の水準に原状回復するための住宅の 補修、改築費用を賠償すること

(2)「移住」希望者に対して
・震災前の水準の住宅を移住希望先で取得す る費用を再調達価格で賠償すること

(3)「避難」継続者に対して

・自治体が提供する災害公営住宅の建設費用 と仮設住宅の建て替えや居住水準を高め るために必要な改修費用を賠償すること

（2）生活の再建

(1)仮設住宅（みなし仮設等を含む）について ・原発災害の特性を踏まえ入居期限を撤廃 し、仮設住宅については長期間の使用に 耐えられるように居住水準を高めるため の建て替えや改修を進めること

(2)住み替えについて

・避難者の生活環境变化に伴う仮設住宅（み なし仮設等を含む）の住み替え（新規を含

む）を認め家賃等の支援を継続すること

(3)生活資金の賠償について

・災害公営住宅の家賃について賠償すること ・避難者が60歳に達した時は資産の散逸と 就労の困難さを踏まえ最低生活水準を年 金方式で賠償すること

（3）避難者の二地域市民権保障

(1)住民としての法的地位について

- 避難継続者については、避難元と避難先の 双方において参政権や教育を受ける権利 等を含む住民としての法的地位を保障す ること

・そのために「二重の住民登録」を制度化す ること

(2)まちづくり参加権について 
・避難継続者については、避難元と避難先の 双方においてまちづくり計画への参画を 保障し、同時に避難期間中の居住環境整 備に関する参加を保障すること

(3)自治体間交流について

・避難継続者については、避難元と避難先と の自治体間、住民間交流を進め、住民同 士が支え合う場を保障すること

（4）政策・制度整備

(1)被ばくを避ける権利について

- 原発災害の特殊性や今後の避難区域の変化 を踏まえ、帰還、移住、避難継続の選択は、 誰からも強要されることなく、当面の間、 避難者個人の判断に委ねられること

-いわゆる「自主避難」者や避難指示解除後 の避難者に対しても、強制避難者と同様 の政策対応をとること

(2)住まいの再建基金について

・「住まいの再建」を早急に進めるために、 国による基金を設立し国が東京電力に代 わって避難者への賠償を直ちに立て替え、 その後に国から東京電力に求償すること

(3)法整備について

・自然災害とは異なる原発災害の特性を踏ま えた災害救助特例法を制定し、上記の内 容を法制化するとともに、東京電力が賠 償するまでの間、国による財政支援を明 記すること

・原発災害事務処理特例法と子ども・被災者 支援法における地域限定を撤廃し、すべ
ての避難者の避難生活の維持と住まいの 再建を保障すること

・原発災害による避難地域を含む自治体の 地方交付税算定にあたっては、当面の間、 2010年国勢調査の人口を利用すること

\section{5 自治体と区域}

このまま避難が長期化すると元の自治体の区 域や住民がいなくなってしまい、自治体の存続 が危うくなるのではないかという質問を受ける ことがある。しかし、そういう指摘は必ずしも 当てはまらない。冒頭に書いたように、本来、 自治体にとって区域とは人がいて存在するもの である。たとえ全国に避難していようと、厳然 と住民がいる以上、自治体の存立根拠を失うこ とはない。

さらに付け加えれば、現在は住めないとされ ているものの、自治体の区域もまた厳然と存在 している。現に、廃炉に向けた作業をはじめと して、さまざまな工事や除染作業が行われてお り、人の数という側面においても、決して震災 前から見劣りするような状況にはない。一部地 域の国有化論が出ているが、仮に国有化された ところでそれは土地の所有権の問題であり、そ こに住み、働き、憩う人々がいる限り、自治体 は存立する。

具体的に考えてみても、現時点で全域避難を している双葉郡 6 町村と飯舘村について、政府 の判断による「帰還困難区域」が全域を占める 
自治体はない。多くの場合、町の中心部は比較 的短期間で帰還できるエリアに入っている。自 治体と区域という問題は、自治体とは何かを考 える際に重要なファクターではあるが、少なく とも当面の問題として、既存の考え方でも自治 体の存立が危うくなることはない。むしろこれ を契機とした自治体再編論があるとすれば、そ れは別の観点からの主張ではないかと思われ る。

原発災害避難者の生活再建やそれを支える自 治体の存立については、ますます厳しい環境に なりつつある。この厳しさはこれまでに日本の 社会が抱えてきた脆弱性の顕在化でもあり、だ からこそ簡単には解決不可能な課題となってい る。しかし、現に 14 万人の原発災害避難者が 現在もいる以上、解決に向けて少しでも前に進 まなければならない。契緊になすべきことも多 数あり、日本学術会議の提言を踏まえた政府の 早急な対応が求められている。 